\title{
EVALUATION OF AN ASSOCIATE DEGREE DISTANCE PROGRAM BASED ON STUDENTS' PERCEPTIONS OF THE PROGRAM COMPONENTS
}

\author{
Dr. H. Mustafa DONMEZ \\ ORCID: 0000-0002-3062-7010 \\ Department of Foreign Languages \\ Eskisehir Osmangazi University \\ Eskisehir, TURKEY \\ Dr. Ayhan HAKAN \\ ORCID: 0000-0002-2493-5658 \\ Open Education Faculty \\ Anadolu University \\ Eskisehir, TURKEY
}

Received: 07/11//2018 Accepted: 19/03/2019

\begin{abstract}
This study aimed to evaluate the Public Relations and Publicity associate degree distance program available to students through Open Education Faculty at Anadolu University, Turkey. The study used Erden's (1998) component-oriented model and a convergent mixed methods design employing an online questionnaire form. The study population included students who had "active student" status in the program during the spring semester 2017. The study sample consisted of 412 students, who submitted complete questionnaire forms. The responses to the closed-ended questions were analyzed using descriptive statistical tools and responses to the open-ended questions were analyzed using descriptive coding. The results showed that the participants had a high level of overall satisfaction with the program, and they particularly had more positive attitudes towards the e-learning platform among all the components. However, they had less positive attitudes towards the textbooks and the measurement and evaluation processes. In addition, the participants who stated that they used the e-learning platform had more positive attitudes towards all the components than the other groups in general. In the light of the results, some suggestions were made to improve the program like reviewing some of the program components such as the textbooks and measurement and evaluation practices.
\end{abstract}

Keywords: Open and distance learning, program evaluation, component-oriented program evaluation, participant-oriented program evaluation.

\section{INTRODUCTION}

Learning-teaching effort has been the driving force of cultural development since the early days of humanity. Each breakthrough that emerged as a result of this effort has been a means for reaching the next threshold in the field of education. One of the developments that can be considered as milestones in the field of education has been the emergence of open and distance learning (ODL) systems. Having developed as an extension of developing technologies and considered as an expanding part of mainstream education, ODL is a planned learning activity that brings together learners and teachers in different physical environments using a variety of technologies, including special communication methods and instructional techniques (Moore and Kearsley, 2005). ODL was born by the opportunities offered by postal services, expanded with radio and television, it became digital with computer assisted practices, and it is now leading a process that develops continuously thanks to the Internet and new information technologies. In this sense, Anadolu University 
(AU) has contributed to this process for decades, and Anadolu University Open Education System (AUOES) constituted $47 \%$ of higher education in terms of the number of students in Turkey in 2014 (Cetinsaya, 2014). Although this ratio decreased to $41 \%$ in 2018 (Turkish Council of Higher Education, 2018), AU is still a leading institution in this area as one of the mega universities in the world (Daniel, 1996). As a matter of fact, many people in Turkey today associate the term Open Education with Anadolu University although there are other Turkish higher education institutions offering ODL programs in the country.

Another milestone in the teaching-learning journey of human beings is the emergence of the concepts of educational planning and educational program. Educational programs are not static structures that are considered to have completed their tasks or are not in need of revision and improvement once they are established. On the contrary, program development is a dynamic activity. One of the main principles underlying program development is the continuity of this activity. Sustainable educational programs that can reach their goals can only be achieved through continuous evaluation with the correct methods, techniques, tools and materials (Hakan, 1991). Therefore, it is vital that any educational program needs to be evaluated using appropriate instruments.

The shift from brick-and-mortar instructional settings towards ODL systems brings with it a need for continuous program evaluation and improvement activities. Considering ODL programs in general, and AUOES in particular, it is vital to continuously evaluate the programs offered and to make the necessary revisions and improvements without delay. In this context, evaluation of learning environments structured with ODL approach by the participants of programs is essential for program development and evaluation activities because distance learners are responsible for their own learning journeys and are the core and direct users of an ODL program.

\section{From Distance Education to Open and Distance Learning}

As an interdisciplinary field, distance education aims to facilitate an instructional activity between learners, teachers and learning resources often by employing existing technologies. According to Simonson et al. (2006), the term "distance education" encompasses a formal instructional process in which learners and teachers are not obliged to be in the same physical environment but still have learning experiences under an institutional and organized structure via instructional technologies. Difficulties of traditional formal education institutions in meeting the increasing demand in every stage of education, the problems encountered in the learning-teaching process to be solved more effectively with new information communication techniques and environments, and opinions on the necessity of providing life-long learning opportunity to every individual who has such a wish have also played an important role in the emergence ODL practices (Hakan, 1996). The concept of openness in ODL, which is strengthened by open educational resources, has also led to the emergence of massive open online courses (McKinney, Dyck, and Luber, 2008). These courses brought about a new phenomenon within the framework of lifelong learning by providing high quality, open and free courses to learners (Kesim and Altinpulluk, 2015). According to Shah (2018), as of 2018, there are 81 million students enrolled in 9.400 mass-open online courses in more than 800 universities around the world. Forcing the boundaries of mainstream education today, ODL is neither solely a result of developments in information and communication technologies nor is it a teaching-learning practice that emerged spontaneously.

There appears to have been a shift from teaching to learning in the field of education with the use of networks in ODL as a widespread technology. Anderson and Dron (2011) focus on pedagogy defining the learning experiences in distance learning-teaching designs, and they emphasize the significance of the pedagogical stance embedded in experiences such as learning activities and roles rather than technology. Considering the stages in the historical development of open and distance learning, there seems to be a paradigm shift from teaching (or instructing, educating, lecturing and so on) to learning in the field and, as a result of this change, there has been a tendency towards "open and distance learning" from "distance education". The reason why our perspective has changed is that ODL continues to evolve in a network-based world, and ODL needs to be addressed within the context and features of this network environment (Oblinger and Kidwell, 2000; Leiner et al., 2009). As an interdisciplinary field of study that takes its foundations from both technology and pedagogy, ODL is probably no longer seen as learning contents or video tutorials distributed via traditional mail infrastructure. 


\section{Anadolu University Public Relations and Publicity Program}

Offered by AU Open Education Faculty (OEF), the Public Relations and Publicity Program (PRPP) has been serving for 25 years and has 19.060 "active students" as of 2017 (AU, 2017). The term "active students" refers to those students who take courses by enrolling or re-registering in a program in AUOES each term. PRPP is a two-year program and students graduating from this program are awarded an associate degree in public relations and publicity. Students are normally admitted to PRPP using new student admission option for high-school graduates through the central student placement exam, transfer admission option, or second university option (i.e., admission without entrance examination for students or graduates of any higher education program). In general, public relations and communication sciences courses are taught in the program. The program courses are offered with the semester credit system (AU, 2018a).

The components of PRPP can be classified as "program objectives", "course contents", "learning environments" and "measurement-evaluation processes". The overall objective of PRPP is to train qualified individuals in public relations sector by teaching students the basic issues related to public relations, practical areas and communication through the content covered by the program. Detailed information about the program outcomes and course contents can be found in the program webpage. PRPP learning environments include textbooks, Anadolum e-Campus system and face-to-face classes for some common courses. The learning materials presented in Anadolum e-Campus can be divided into four groups: PDF type, audio, video, and interactive learning materials (Buyuk et al., 2018). PRPP courses' contents are also delivered through faceto-face classes, which OEF students can participate in free of charge. However, among these courses, PRPP students can only attend English I-II courses. The last component of PRPP is measurement and evaluation processes. PRPP students sit two face-to-face exams in each term: one midterm and one final exam that are conducted at weekends. There are make-up exams that students can sit if they fail only a maximum of three-courses in total. The exam for each course consists of 20 questions and the duration of each test is 30 minutes. Students can chose among examination venues assigned by AU according to their places of residence. The exam results are announced in about 15 days after exam dates. In accordance with AU regulations for examinations, one-fourth point is deducted for each wrong answer. Midterm exams weigh $30 \%$ and final exams weigh $70 \%$ of a student's achievement grade in a course (AU, 2018a).

\section{Program Evaluation in Open and Distance Learning}

Tyler (1949 as cited in Fitzpatrick, Sanders and Worthen, 2004) defines program evaluation as a process for determining the extent to which a program has attained its objectives. According to Brown (1995), program evaluation involves evaluating the effectiveness of the program as well as the attitudes of the participants by collecting all the information needed to promote the improvement of a program in a systematic way. Program evaluation is also a process that focuses on all or certain aspects of a particular program (Kristoffersen, 2003). Posner (2004), on the other hand, defines program evaluation as a decision-making process for the value of the components of a program. Openness and transparency plays a vital role in effective management. Therefore, everything from an organization's vision and mission to the tools it uses to achieve these must be open to continuous evaluation and redesign if necessary (Paul, 2003). There are certainly numerous requirements that need to be met by any higher education institution to achieve the perfection of its activities, and efforts to maintain quality and supremacy are in no way less important than the other things.

The boundaries between ODL and traditional face-to-face education are becoming gradually blurred, and these two forms of learning are approaching each other through information and communication technologies, networked flexible learning, and credit transfer/accreditation mechanisms (Tait and Mills, 1999). For this reason, program evaluation and accreditation is gaining more importance in ensuring quality. In addition, higher education institutions around the world, in parallel with the increasing enrollment rates and costs, face further pressures on providing information to both students and taxpayers about the pedagogical approaches they adopt and the outcomes they have achieved (Garrett, 2016). It is an undeniable fact that the ever-increasing enrollment rates raise doubts about whether it is possible to provide quality education at the same time while meeting the educational needs of such crowded learner groups. For this reason, it is essential to evaluate ODL programs in terms of program design for learning materials, content organization, distribution method, and student assessment practices. 
A successful instructional design in ODL can only be achieved as a result of successful management of design development, implementation and evaluation. Like Powar (2003), who argues that an open university consists of administrative, academic, production distribution and student support components, Inglis (2003) and Khan and Garg (2003) advocate that program evaluation is one of the main activities of ODL organizations. Delivering ODL activities requires a nested set of systems and processes to be employed, and the only way to understand whether each is functioning correctly is possible through evaluation. Therefore, ODL systems should continuously be reevaluated and improved.

Ascough (2002) suggests that the same tools used in face-to-face learning should be used when evaluating an ODL program as far as possible; however, some questions that are specific to ODL should be included in these tools, too. Then the question remains how to evaluate a face-to-face or open and distance education program. Various researchers and educators have proposed different classifications and approaches on program evaluation (Erturk, 2013; Fitzpatrick, Sanders and Worthen, 2004; McNeil, 1996; Ornstein and Hunkins, 2004; Posner, 2004; Stake, 1967; Stufflebeam, 1971; Tyler, 2013; Usun, 2012; Yuksel and Saglam, 2014). For example, the Kirkpatrick model, one of the most well-known and used frameworks for the classification of program evaluation activities (Aluka and Shonubi, 2014; Tamkin, Yarnall and Kerrin, 2002), consists of four steps: Reactions, Learning, Behaviors (Attitudes) and Results (Sercek-Ozaltas, 2014). On the other hand, Fitzpatrick, Sanders and Worthern (2004) categorize the approaches to program evaluation in six groups: objectives-oriented, management-oriented, consumer-oriented, expertise-oriented, adversaryoriented, and participant-oriented approaches.

Evaluation of ODL programs should focus on the following factors: a) to what extent the intended student learning outcomes have been achieved, b) the types of unexpected results obtained, c) students' satisfaction with the quality of teaching, and d) usability of learning materials (Inglis, 2003). In this study both component-oriented and participant-oriented program evaluation approaches were used in an eclectic way to evaluate the objectives, course contents, learning environments and measurement and evaluation processes of PRPP based on PRPP students' perceptions.

\section{Component-Oriented Program Evaluation Model}

According to Erden (1998), there are two essential questions that need to be asked when evaluating an educational program: 1 . To what extent does the program achieve its objectives? and 2 . What are the main weaknesses and problems in the program? The answers to the first question take us to what Erden (1998, p. 19) calls "evaluation based on outcomes and achievement" while the answers to the second question involve "evaluation based on the components of a program". The first type of evaluation gives an idea of the extent to which the program is effective in achieving the objectives, but it may cause us to miss out on the aspects in need of improvement. Therefore, in order to determine these weaknesses and to make the necessary revisions, all the components of a program should be evaluated (Bayrak and Erden, 2007). Educational programs have four basic components: objectives, content, teaching-learning environments, and measurement and evaluation processes (Ayvaz, 2001; Erden, 1998; Kocabatmaz, 2011; Nas, 2003). Similarly, the model of educational strategies developed by Taba (1962) is based on the relationship between five mutually interactive components: goals, content, learning experiences, teaching strategies and assessment criteria. Such a model of evaluation, which focuses on the components that constitute a program, is called a component-oriented evaluation model. The stages in which Erden (1998) addresses program evaluation activities in this model are shown in Figure 1. 


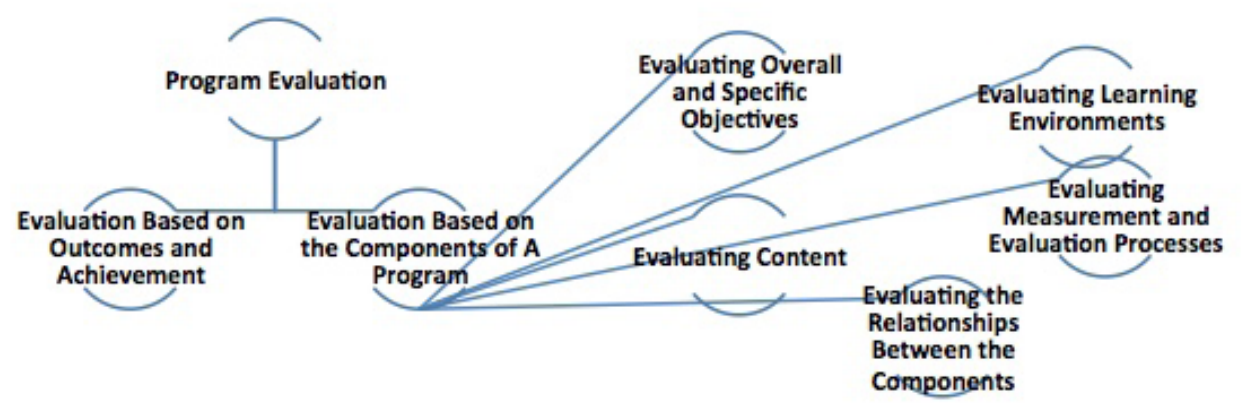

Figure 1. Stages in the component-oriented program evaluation model (Erden, 1998)

\section{Participant-Oriented Program Evaluation}

The participant-oriented evaluation approach focuses on the issues, topics and outcomes of an educational activity by highlighting the views of the participants. It also suggests that inclusion of participants in the process can be useful and important (Boody, 2009; Hogan, 2007; Tunc, 2010). Indeed, according to Cousins and Earl (1995), this approach is appropriate for evaluation activities aimed at collecting data about the functioning of a program and improving the program. Fitzpatrick, Sanders and Worthen, (2004) emphasize the need for the evaluator to try to describe the needs and views of program stakeholders. As Kucuk (2008) points out, the participant-oriented program evaluation approach emphasizes the importance of participants in the process and guides the evaluators about the participation of stakeholders, evaluation criteria, values, needs and data. Similarly, according to Yuksel and Saglam (2014), who argue that most program evaluation studies are carried out without considering the environments and conditions in which the program is implemented and without a particular focus on human factor, a participant-oriented program evaluation model aims to observe and define expectations, problems and recommended solutions.

In this study, exploring the opinions of PRPP students as first-hand users of PRPP is considered important because involvement of stakeholders in the decision-making process yields positive results in the name of efficiency. In fact, students' views on the assessment mechanisms are very valuable for decision-making processes (Powar, 2003). The person who has a problem is, in a sense, an expert on the problem, he or she is the one who can best understand the problem and what can be done to solve the problem, and often the solution of the problem should start with that person (McNamara, 2009). Therefore, any evaluation activity of an ODL program should involve participation of users, or distant learners (Gajanayake and Gajanayake 1993 as cited in Braimoh, 2003). This is often because individuals who are core users of an educational program and have first-hand knowledge and experience about instructional activities could make the best evaluation.

\section{PURPOSE OF THE STUDY}

Identifying PRPP students' perceptions of the program could be considered as a need in order to improve this program. Students, perhaps the most important group among the stakeholders of an educational program, have a significant place in any program. Therefore, in this study, the need to evaluate the components of PRPP based on student opinions is seen as a problem. In today's world, individuals make evaluations or reviews of the products and services they use via the Internet and social media channels and they also benefit from the evaluations made by other users (Duan, Gu and Whinston, 2008). These evaluations can serve as feedback for both other potential users and those who provide services. In this sense, this study could contribute to all the stakeholders of the program by identifying the expectations and opinions of PRPP students about the program components. Also, since there is limited research on the evaluation of AUOES programs, which have approximately 1 million active enrolled learners, and no program evaluation study specifically designed for PRPP has been conducted before, this study could help eliminate the gap in this field and help the PRPP administrators make informed decisions. In the light of these considerations, the aim of this study is to evaluate Anadolu University Open Education Faculty "Public Relations and Publicity" program according to the opinions of the program students about the program components with a participant-oriented approach. Therefore, this study addresses two main questions: 
1. What do PRPP students think about the program objectives, course contents, learning environments, and measurement and evaluation processes?

2. Do the students' opinions about the PRPP components vary according to their status of employment, reasons for enrolling in the program, type of enrollment in the program, willingness to continue with a bachelor's degree, and use of learning environments?

\section{METHODOLOGY}

This study used a convergent mixed methods design employing an online 59-item questionnaire form to evaluate Anadolu University Open Education Faculty "Public Relations and Publicity" program according to the opinions of the students and based on the program components with a participant-oriented evaluation approach. By means of convergent (or parallel or concurrent) designs both quantitative and qualitative data can be collected, integrated and analyzed concurrently in a single study to compare or combine two sets of results (Creswell and Plano Clark, 2011). Erden's (1998) component-oriented program evaluation model was used in this study because it helps determine the impact of the contents, learning environments and measurement and evaluation processes of a program on achieving the objectives of the program (Eksioglu and Taspinar, 2014). The reason for the need for such an evaluation approach is that in educational settings, the identification of aspects of any program component that are weak or in need of improvement will affect both teaching activities (processes) and outputs (products) of the program (Mede and Akyel, 2014). Also, a participant-oriented program evaluation approach was used in this study. The primary reason for this choice is that when conducting a program evaluation based on program components, evaluators need to receive participants' opinions on all the components of a program.

\section{Participants}

The study population included a total of 19.060 PRPP students in their first or second year of study that had "active student" status during the spring semester 2017. No sampling strategies were employed in this study, because it was practically possible to reach the entire population using online tools. Considering the fact that the population included 19.060 students, the number of complete submissions of the questionnaire form (N: 412) was considered to be sufficient for a sample size that can represent the population (Bartlett, Kotrlik and Higgins, 2001; Cochran, 1964 as cited in Balci, 1995). Among the entire population (N: 19.060), $56.27 \%$ were male, $88.33 \%$ enrolled in the program through the central student placement system, $71 \%$ were 28 years old or older, and $67.48 \%$ were employed (AU, 2017). Similarly, among the participants in our study, $64.3 \%$ were male, $86.9 \%$ enrolled in the program through the central student placement system, $74.3 \%$ were 31 years old or older, and $77.4 \%$ were employed. In other words, the study sample was similar to the population in terms of these basic characteristics.

\section{Data Collection and Analysis}

Both the quantitative and qualitative data for this study were collected using the questionnaire technique. It is possible to collect large amounts of data by reaching the masses using the questionnaire technique (Bas, 2001; Balci, 1995). Data were collected using the "Evaluation Survey for Public Relations and Publicity Program" (see Appendix A) developed by the researchers based on the relevant literature (AU, 2016; Baraz, 2005; Hakan 1996; Usta, 2015; Yavuz, 2007). The quantitative data were analyzed using the Statistical Package for the Social Sciences (SPSS Version 20) and presented as number (N) and percentage (\%). In addition, using statistical methods, the researchers looked for the cross-relationships between certain characteristics of the students (i.e., status of employment, reasons for enrolling in the program, type of enrollment in the program, willingness to continue with a bachelor's degree and use of learning environments) and their responses to the closed-ended questions. The data were then interpreted using arithmetic mean $(\bar{x})$ and standard deviation (SD). The students' responses to the four open-ended questions were analyzed using descriptive coding. The main topic of each response in this part was summarized in a word or a phrase to obtain a categorization. In the entire sample ( $\mathrm{N}: 412$ ), the total number of participants responding to at least one of the four openended questions that were optional was 245. Each of these students was given a pseudonym (Student 1 , 
Student 2,... Student 245). The answers to each open-ended question were transferred to a word processor and then the researchers read the answers of each participant to the open-ended questions repeatedly and the categories of opinions about the program components were coded with key words or phrases. The frequency of the obtained categories within the total responses was also determined.

\section{The Scale}

The "Evaluation Survey for Public Relations and Publicity Program" was developed by the researchers based on questionnaires used in in similar studies (AU, 2016; Baraz, 2005; Hakan 1996; Usta, 2015; Yavuz, 2007). This questionnaire included both closed-ended and open-ended questions. A total of seven people with expertise in program evaluation in ODL - two professors, an associate professor, two instructors with $\mathrm{PhD}$ degree and two instructors - reviewed the questionnaire in order to determine its appropriateness for the research aims and the comprehensibility of the expressions. The questionnaire form was then revised in the light of the feedback given by these experts.

The questionnaire was piloted with 10 PRPP students - seven male and three female students. Final revisions were made on the questionnaire and these 10 students were not included in the study sample. After obtaining the required permissions from AU Graduate School of Social Sciences, Open Education Faculty Dean's Office and Ethics Committee, an announcement about the questionnaire was made on Anadolum e-Campus system exclusively for PRPP students. The announcement included a link to the questionnaire form published online. The questionnaire form was online between May, 2017 and June, 2017. On the first page of the questionnaire, the participants were informed about the purpose of the study and the confidentiality of the information they were going to provide, and they were able to move on to the other parts only if they checked the box stating that they accepted these conditions.

The Evaluation Survey for Public Relations and Publicity Program consists of 59 items in three parts. The first and second parts of the questionnaire are designed to collect quantitative data using close-ended questions whereas the third part aims to collect qualitative data using open-ended questions. The first part of the questionnaire includes 12 items about the participants' gender, age, marital status, types of high schools they graduated from, city of residence, year of study, employment status, reasons for enrolling in the program, type of enrollment in the program, willingness to continue with a bachelor's degree, use of learning environments forms, and compliance with the preparation guidelines for OEF exams. The second part includes 43 positively worded items under seven headings: objectives of the program (3 items), contents of the courses in the program ( 6 items), textbooks (5 items), e-learning environments ( 7 items), measurement and evaluation (9 items), opinions and suggestions for improving the program (11 items) and general level of satisfaction with the program ( 2 items). In this part, respondents are asked to rate their level of agreement with the statements about the program using a 5-point Likert scale (1=Strongly Disagree, 2=Disagree, $3=$ Neither Agree nor Disagree, 4=Agree, and 5=Strongly Agree). The third part of the questionnaire includes four optional open-ended questions to identify the participants' opinions about the program components and their solution proposals to the problems as they perceive.

\section{FINDINGS}

Among the participants in our study, $64.3 \%$ were male, $86.9 \%$ enrolled in the program through the central student placement system (i.e., new student admission or transfer admission), $74.3 \%$ were 31 years old or older, $66.7 \%$ of the participants were married, about half of them (45.1\%) graduated from regular public high schools, more than half of them (52.9\%) were in their second year of study, and more than half of them (54.9\%) stated that they did not follow the preparation guidelines for OEF exams.

The participants' employment status is shown in Figure 2. As can be seen in Figure 2, more than threequarters of the participants $(77.4 \%)$ stated that they were employed. 


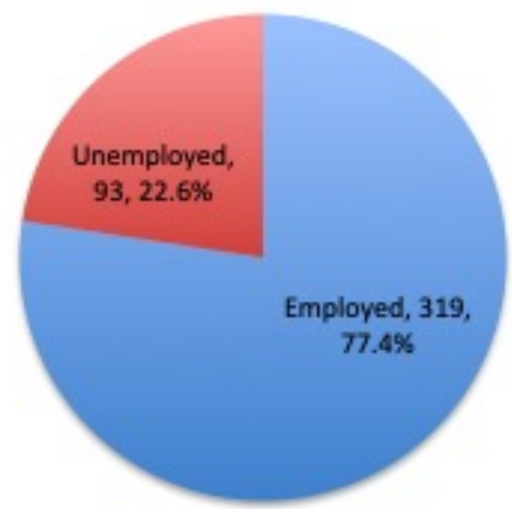

Figure 2. The participants' employment status

Analysis of the reasons given by the participants to enroll in PRPP suggests that the program was primarily seen by the participants as a tool to achieve career goals as can be seen in Figure 3 below.
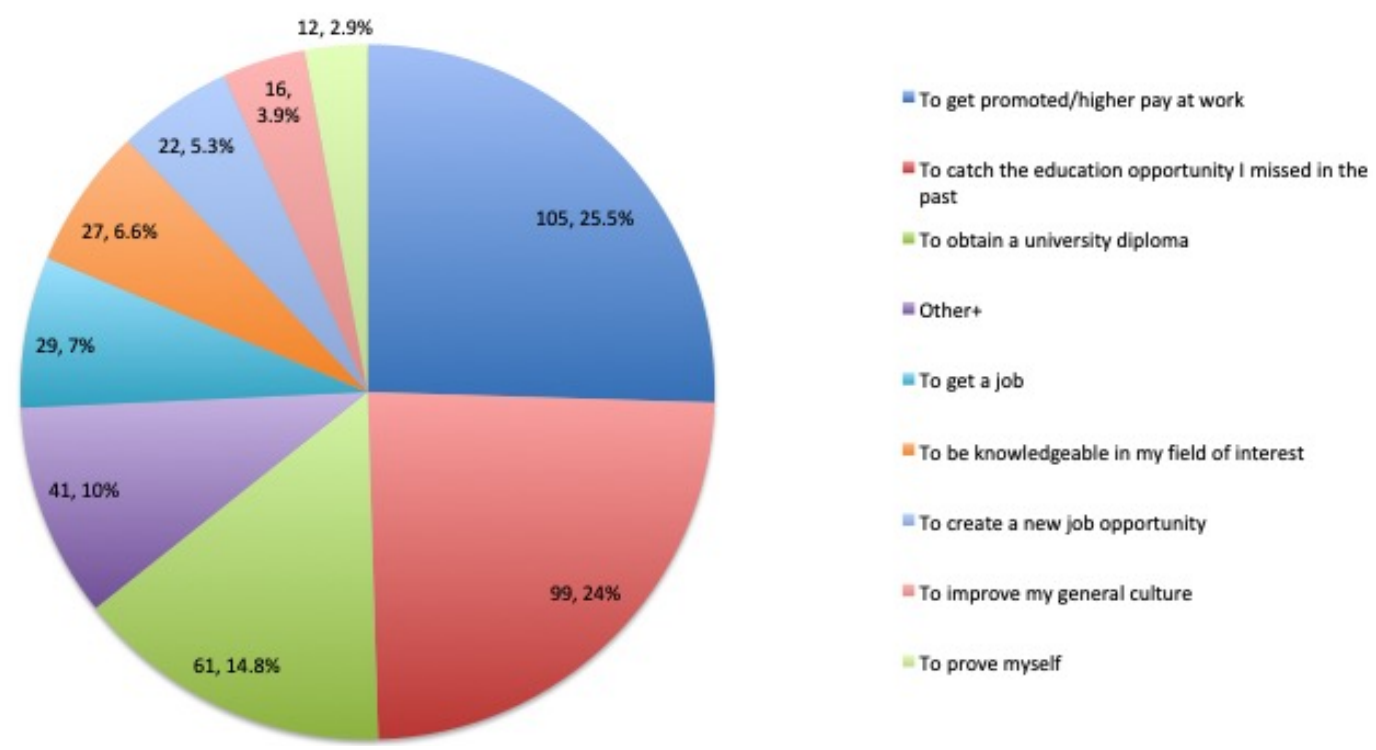

Figure 3. Distribution of reasons for the participants to enroll in PRPP

The following options, which were originally given in the questionnaire separately, were brought together under "Other" option during the data analysis process since the highest percentage among them was $2.7 \%$ and their sum was $10 \%$ : To learn about topics related to my profession, Because attendance is not required, Because my level of income is not sufficient for education in another city, To delay my compulsory military service, Because having an open education diploma is a privilege, To earn a respectable social status, My exam score was only sufficient for distance education, To be a university student, and Because people around me encouraged me.

As can be seen in Figure 3, the most popular reason for enrolling in the program was getting promoted/ higher pay at work $(25.5 \%)$, followed by catching the education opportunity they missed in the past $(24 \%)$ and obtaining a university diploma (14.8\%), which indirectly serve for career. On other hand, very few participants $(2.9 \%)$ stated that they enrolled in the program in order to prove themselves.

As can be seen in Figure 4 below, the vast majority of the participants (86.9\%) stated that they enrolled in PRPP using the new student admission or transfer admission options. 


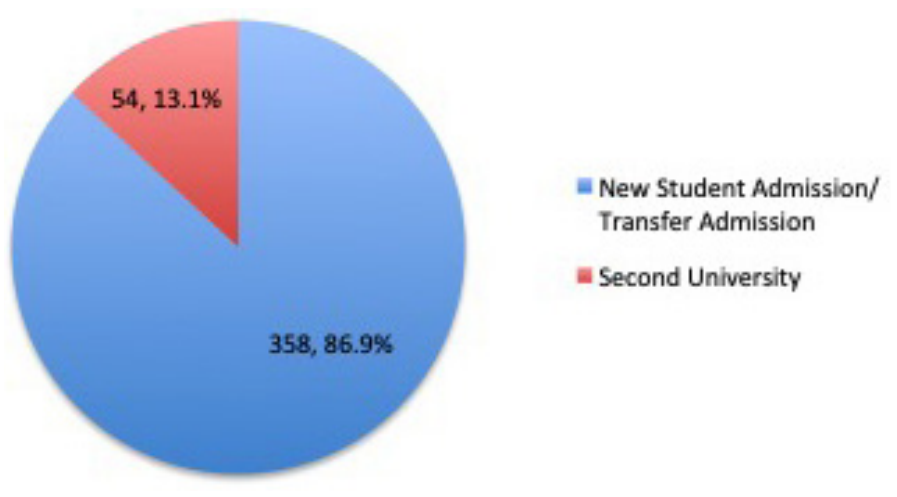

Figure 4. Distribution of types of enrollment in PRPP

Nearly three-quarters of the participants stated that they were willing to continue with a bachelor's degree after graduating from PRPP (Figure 5).

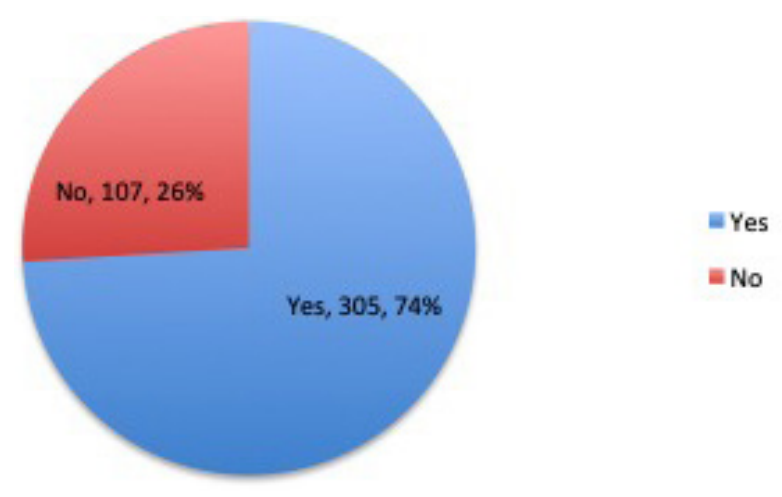

Figure 5. The participants' willingness to continue with a bachelor's degree

As can be seen in Table 1 below, the majority of the participants used Anadolum e-Campus (82.3\%) and textbooks $(73.3 \%)$, but most of them $(72.8 \%)$ did not attend face-to-face classes.

Table 1. The participants' use of PRPP learning environments

The options "Never" and "Rarely" in the original questionnaire form were coded as "No" while the option "Very often" was coded as "Yes" during the data analysis process.

\begin{tabular}{lll}
\hline Use of PRPP learning Environments & $\mathrm{N}$ & $\%$ \\
\hline Textbooks & 302 & 73.3 \\
Yes & 110 & 26.7 \\
No & 412 & 100 \\
Total & & \\
Anadolum e-Campus & 339 & 82.3 \\
Yes & 73 & 17.7 \\
No & 412 & 100 \\
Total & & \\
Face-to-face Classes & 300 & 72.8 \\
No & 112 & 27.2 \\
Yes & 412 & 100 \\
Total & & \\
\hline
\end{tabular}


Among all the PRPP learning environments, the most preferred learning environment was Anadolum e-Campus while the least popular one was face-to-face classes. Actually, regarding the open-ended question about this topic, less than half of the participants (48.8\%) stated that there was a need for face-to-face classes.

The participants generally had positive opinions about the program objectives and more than half of them expressed that the objectives could meet learners' needs (54.6\%), they were stated clearly (53.9\%), and they could be used in everyday life (51\%).

The participants generally had positive attitudes towards the program contents, too. The majority of the participants stated that the contents improved their general culture $(65.3 \%)$ and more than half of them stated that the contents could achieve program objectives (52.2\%). On the other hand, the majority of them stated that elective courses offered in the program should be diversified (62.7\%), they should be able to take courses in other programs (60.2\%), and there was a need for supplementary resources $(65 \%)$. Another aspect of the program contents about which the participants had less positive opinions was the extent to which the contents improved professional knowledge. (46.1\%) Likewise, in the study of Baraz (2015), the participants disagreed most with the statement suggesting program textbooks contained sufficient professional knowledge. In addition, less than half of the participants stated that the contents were clear and easy to understand $(46.8 \%)$. This result was also evident in the responses to the open-ended questions as can be seen in Table 2.

Table 2. Opinions about PRPP textbooks and contents

\begin{tabular}{ll}
\hline Opinions & Frequency \\
\hline The need for textbooks to be shorter and summative & 89 \\
Satisfaction with textbooks and contents & 18 \\
The need for more exam practice questions in textbooks & 16 \\
Dissatisfaction with the use and portability of printed books & 8 \\
The need for presentation in Turkish in foreign language books & 7 \\
Dissatisfaction with the out-of-date contents & 4 \\
Dissatisfaction with inconsistency between textbooks and exam contents & 3 \\
Total Number of Students Responding to the Question & 145 \\
\hline
\end{tabular}

As can be seen in Table 2, the majority of the participants who responded to the open-ended question about the PRPP textbooks and contents (N: 89) expressed their need for shorter textbooks that summarize course contents. For example, Student 18, wrote, "Very long sentences and unnecessary stories were used in the textbooks. Textbooks should be more summative", and Student 20 wrote, "None of the students I know use the textbooks. Instead, it should be like the books we buy outside the school in which the courses are compiled in a single book." Only $36.9 \%$ of the participants stated that the textbooks contained units with sufficient number of exam practice questions. With regard to the contents of the textbooks, the need for more exam practice questions was also evident in the responses of the participants to open-ended questions. For example, Student 24 wrote, "Please increase the number of exam practice questions at the end of units, e-Campus worksheet questions are the same as those in the textbooks," and Student 148 wrote, "It's already hard to study when you have a job, so I can't usually study with textbooks. I just read the summary and question-answer sections. End-of-unit tests in textbooks are not enough." On the other hand, although the level of satisfaction with the textbooks was found to be relatively low in this study, the vast majority of the participants stated that they used the textbooks $(88.9 \%)$.

In contrast to the results about the textbooks, the participants had more positive opinions about the e-learning environments of the program in general and the statements that they agreed with most on average were in this part of the questionnaire (59.54\%) after the part about the general level of satisfaction with the program $(63.75 \%)$. The majority of the participants stated that the e-learning environments of the program ensured revision of the subjects (62.6\%), they were suitable for individual learning $(60.9 \%)$, and they could be used by anyone with basic computer skills $(67.4 \%)$. Also, more than half of the participants stated that 
the e-learning environments facilitated learning (58.3\%), they supplemented the textbooks (58\%), they prepared for the exams (56.6\%) and they contained all the knowledge related to the program (53\%). Despite these positive attitudes towards the e-learning environments, the participants had a lower level of agreement with the statement on the adequacy of the content coverage of this platform. These results are also reflected in the responses given to the open-ended questions. The participants' responses to the open-ended question about the PRPP learning environments are summarized in Table 3.

Table 3. Opinions about PRPP learning environments

\begin{tabular}{ll}
\hline Opinions & Frequency \\
\hline Satisfaction with learning environments & 41 \\
The need more exam practice in learning environments & 21 \\
Dissatisfaction with inadequacy of contents in learning environments & 20 \\
Difficulty in accessing learning environments & 10 \\
The need for face-to-face classes & 7 \\
Dissatisfaction with inconsistency between learning environments and exam contents & 5 \\
Dissatisfaction with learning environments being out-of-date & 3 \\
Total Number of Students Responding to the Question & 107 \\
\hline
\end{tabular}

Among the participants who responded to the open-ended question about the PRPP learning environments (N: 107), 41 students expressed their satisfaction with the learning environments as can be seen in Table 7. For example, Student 11 wrote, "Successful, thanks to those who contributed," and Student 197 wrote, "Everything is perfect, I think we, as students, should spend a little effort and study regularly. That would be enough." On the other hand, the participants' self-reported need for more exam practice questions was again evident in other responses to the same question. In fact, 21 responses among these expressed this need in some way. For example, Student 56 wrote, "Textbooks should be shorter and be in the form of question banks," and Student 159 wrote, "It would be better if you gave a lot of questions from previous exams or possible questions for future exams."

The participants had less positive opinions about the PRPP measurement and evaluation practices. For example, the majority of the participants stated that the number of questions in the exams was sufficient $(63.9 \%)$ and time given in exams was sufficient (70.6\%). However, the statements that the participants disagreed with most on average were in the part about the PRPP measurement and evaluation processes (50.43\%) after the one about the textbooks (47.96\%). For example, less than half of the participants stated that exam questions were consistent with textbook contents (45.6\%), preparation times duration for midterms and final exams were sufficient (45.9\%), applying a lower limit of achievement grade was appropriate $(45.1 \%)$, and determining a student's achievement grade based on his or her performance relative to the class as a whole was an appropriate assessment (45.8\%). In addition, only one third of the students (32.1\%) stated that the principle that midterm exams weigh $30 \%$ and final exams weigh $70 \%$ of a student's achievement grade in a course was appropriate. In fact, nearly half of the answers to the relevant open-ended question revealed the students' dissatisfaction with the examinations of the courses due to the rule "one-fourth point is deducted for each wrong answer" (Table 4). 
Table 4. Opinions about PRPP measurement and evaluation processes

\begin{tabular}{ll}
\hline Opinions & Frequency \\
\hline Dissatisfaction with the rule "one-fourth point is deducted for each wrong answer" & 89 \\
Dissatisfaction with the difficulty level of exam questions & 45 \\
Satisfaction with examination processes & 12 \\
The need for more exam practice questions & 10 \\
Inconsistency between learning contents and exam questions & 9 \\
Dissatisfaction with the time period between midterm and final exams & 5 \\
The need for make-up exams for three courses at the end of fall semester & 4 \\
Difficulty of access to exam locations & 4 \\
Dissatisfaction with exam results & 3 \\
Dissatisfaction with the exam weightings & 2 \\
Total Number of Students Responding to the Question & 183 \\
\hline
\end{tabular}

For example, Student 31 wrote, "I don't understand why there is such a rule in open education when they don't have it in face-to-face education. We're people of a certain age group. We study in difficult conditions, I'd like you to remove it", and Student 200 wrote,

We are in favor of returning to the old exam system, 4 wrong answers eliminating one correct answer... this model is just not the right method for this education. We want the bell curving system, and we demand that we get rid of this system of 4 wrong answers (I use the first-person plural because it is the common opinion of all friends in this system that I have met).

In fact, among the participants who responded to the open-ended question about the PRPP measurement and evaluation processes (N:183), only 12 students expressed their satisfaction. The participants also expressed their dissatisfaction with the difficulty level of exam questions. For example, Student 82 wrote, "Questions are very difficult and tricky, and we cannot already study in detail during preparation for exams," and Student 166 wrote, "Exams are really hard. I'm surprised that we have such hard questions in our department. Please make questions easier." To sum up, the participants' concerns about exams became more evident in both the closed-ended and open-ended questions directly related to the measurement and evaluation processes

This concern was noticeable even in the questionnaire parts about other PRPP components. The most noteworthy results regarding the propositions for the improvement of the program were also related to the subject of measurement and evaluation in some way. The vast majority of the participants stated that they needed make-up exams (80.8\%). On the other hand, more than half of the participants in our study stated that multiple-choice tests were suitable for measuring academic achievement $(50.7 \%)$ and, in the same way, only $25.4 \%$ of them stated that other types of questions (e.g., true-false, open-ended, matching, etc.) should be used in addition to the multiple-choice questions. As can be seen in Table 5 below, around half of the participants ( $\mathrm{N}$ : 56) who responded to the open-ended question about their comments or suggestions to find solutions to the problems about PRPP components (N: 126) expressed recommendations about the PRPP measurement and evaluation processes. 
Table 5. Comments or suggestions to find solutions to the problems

\begin{tabular}{ll}
\hline Suggestions & Frequency \\
\hline Suggestions for measurement and evaluation processes & 56 \\
Suggestions for e-Learning environments & 18 \\
Satisfaction with instructional activities & 17 \\
Need for support services & 9 \\
Suggestions for exam locations & 7 \\
Views on foreign language courses & 5 \\
The need for more exam practice questions & 5 \\
Suggestions for textbooks & 4 \\
Need for face-to-face classes & 3 \\
Views on the central exam for transfer to a bachelor's degree program & 3 \\
Total Number of Students Responding to the Question & 126 \\
\hline
\end{tabular}

On the other hand, the majority of the participants stated that they were pleased to study in this program $(64.8 \%)$ and they would recommend PRPP to another friend (62.7\%). For example, Student 16 wrote, "I haven't had any problems according to my own evaluation", and Student 112 wrote, "The rest is great. Thank you. What is left to is just to study." Despite their satisfaction, however, less than half of the participants stated that they were provided with sufficient information about the validity of the diploma to be given to them when they graduated $(46.6 \%)$ and the majority stated that the program of PRPP should be continuously developed and expanded (69.5\%).

Among all the groups in this study, in comparison with the unemployed participants, those who were employed had less positive attitudes towards all the parts in the questionnaire: the program objectives $(\overline{\mathrm{x}}$ : 3.23, SD: 1.20), contents ( $\bar{x}: 3.23$, SD: 1.12), textbooks ( $\bar{x}: 3.08, S D: 1.10)$, e-learning environments $(\bar{x}$ : 3.41, SD: 1.17), and measurement and evaluation processes ( $\bar{x}: 3.13$, SD: 1.01). Also, their overall level of satisfaction with the program was also lower than the other groups of the participants ( $\bar{x}: 3.50$, SD: 1.29).

In terms of the reasons for enrolling in PRPP, in comparison with the participants stating other reasons, those who stated that they enrolled in the program to prove themselves had more positive opinions about all the program components except for the program objectives ( $\bar{x}: 3.27$, SD: 1.09): contents ( $\bar{x}: 3.53$, SD: .64), textbooks ( $\bar{x} 3.72$, SD: .70), e-learning environments ( $\bar{x}: 3.64$, SD: 1.03), and measurement and evaluation processes ( $\bar{x}: 3.56, S D: .92)$. On the other hand, the participants who stated that they enrolled in PRPP to improve their general culture had less positive opinions about all the parts in the questionnaire: the program objectives ( $\bar{x}: 2.68, S D: 1.25)$, contents ( $\bar{x}: 2.96$, SD: 1.18), textbooks ( $\bar{x}: 2.23$, SD: 1.18), e-learning environments ( $\bar{x}: 2.26, S D: 1.32)$, and measurement and evaluation processes ( $\bar{x}: 2.63$, SD: 1.25).

In terms of the type of enrollment in PRPP, in comparison with the participants who enrolled in the program through new student admission, those who enrolled through the second university option had more positive opinions about all the program components: program objectives ( $\overline{\mathrm{x}}: 3.30$, SD: 1.21), contents ( $\overline{\mathrm{x}}: 3.38$, SD: $1.15)$, textbooks ( $\bar{x}: 3.14$, SD: 1.07), e-learning environments ( $\bar{x}: 3.54$, SD: 1.15), and measurement and evaluation processes ( $\bar{x}: 3.23$, SD: .95).

Also, in terms of willingness to continue with a bachelor's degree after graduation from PRPP, in comparison with the participants who were not willing to continue with a bachelor's degree after graduation, those who had such a wish had more positive opinions about all the program components: program objectives $(\bar{x}: 3.36$, SD: 1.20$)$, contents $(\bar{x}: 3.38, S D: 1.09)$, textbooks $(\bar{x}: 3.17$, SD: 1.07), e-learning environments $(\bar{x}: 3.53$, SD: 1.15), and measurement and evaluation processes ( $\bar{x}: 3.23$, SD: .99).

Finally, in terms of the use of the PRPP learning environments, in comparison with both the participants who used the textbooks and face-to-face classes and those who used neither the textbooks nor face-to-face classes, the participants who used Anadolum e-Campus had more positive attitudes towards all the components of the program: the program objectives $(\bar{x}: 3.43$, SD: 1.13), contents $(\bar{x}: 3.45$, SD: 1.02$)$, textbooks $(\bar{x}: 3.22$, SD: 1.04), e-learning environments ( $\bar{x} 3.67$, SD: 1.06$)$, and measurement and evaluation processes $(\bar{x} 3.28$, SD: .94). On the contrary, the participants who did not use Anadolum e-Campus had less positive attitudes towards all the components of the program. 


\section{CONCLUSION AND RECOMMENDATIONS}

The results in the current study showed that the study sample was similar to the population in terms of basic characteristics such as sex, age, type of enrollment in the program and employment status. More then three-fourths of the participants were employed. Similarly, among all the PRPP students in 2017, 67.48\% were employed (AU, 2017). Also, 80\% of all OEF students in 2016 (AU, 2016) and 83\% of the participants in Usta’s (2015) study were similarly employed. In a study conducted by the European Union Lifelong Learning Program with 1773 ODL students (Schneller and Holmberg, 2014), a typical distance learner was described as a middle-aged individual with a family, child and/or job responsibilities. These findings suggest that PRPP is usually preferred by employed adults.

Our results revealed that the program was primarily seen by the participants as a tool to achieve their career goals. In fact, the most popular reason for enrolling in the program was getting promoted/higher pay at work, followed by other career-related motives Similarly, Baraz (2015), Yavuz (2007) and Usta (2015) found that the most popular reason among their participants for enrolling in an OEF program was to have better career opportunities. Also, Karadag (2014) found that being employed was a leading reason for enrollment in an ODL program, and getting promoted/higher pay at work was a strong motive for the participants for enrollment in OEF in $2016 \mathrm{AU}$ report (AU, 2016). In light of these findings, we could suggest that the program was preferred by the participants because of the advantages it offered to its learners in terms of career rather than due to various obligations. It is reasonable to suggest that the only way for these people to continue their education and gain new qualifications for a new job or position is through ODL.

The majority of the participants stated that they used Anadolum e-Campus and textbooks, but most of them did not attend face-to-face classes. Among all the PRPP learning environments, the most preferred learning environment was Anadolum e-Campus while the least popular one was face-to-face classes. In fact, less than half of the participants stated that there was a need for face-to-face classes. Ucar (2012) found that the majority of AU English Language Teaching program used the online learning environments of the program whereas Usta (2015) found that the students in OEF Social Sciences program did not use the e-learning environments much.

In general, the participants had positive opinions about the program objectives and more than half of them stated that the objectives were stated clearly, they met learners' needs, and they could be used in everyday life. This suggests that the participants were pleased with the program objectives and the department is doing well in this regard.

The participants also had positive attitudes towards the program contents in general. The majority of the participants thought the contents improved their general culture and more than half of them stated that the contents could achieve program objectives. On the other hand, the majority of them wanted to take various elective courses and courses in other programs, and they wanted supplementary resources. The majority of the participants expressed their need for shorter textbooks that summarize course contents. Similarly, most of the participants in the study of Usta (2015) stated that the contents of especially textbooks were too long and detailed. According to 2016 AU report (AU, 2016), 65\% of OEF students used supplementary resources and the most common reason for using these resources was that these resources contained a brief summary of the units in the textbooks. Nevertheless, $62 \%$ of OEF students in the same AU report (AU, 2016) and the majority of the participants in the study of Yavuz (2007) stated that the language of OEF textbooks were clear and readable. More than half of the participants in the current study did not think the program contents improved professional knowledge. Likewise, in the study of Baraz (2015), the participants disagreed most with the statement suggesting program textbooks contained sufficient professional knowledge. In this study, the need for more exam practice questions in learning contents was highlighted in both the responses to close-ended and open-ended questions. Similarly, in the studies of Baraz (2005), Karadag (2014) and Usta (2015), the majority of the participants found the exam practice questions given at the end of units insufficient. On the other hand, although the level of satisfaction with the textbooks was found to be relatively low in this study, the vast majority of the participants stated that they used the textbooks. The interest in textbooks was also still high in different studies investigating AUOES students' views about the system (Hakan, 1991; Hakan, 1996; Hakan et al., 2013; Ozkul and Aydin, 2012; Usta, 2015). In the light of these results, we could suggest that although the opinions of the participants about the textbooks of the program was not very positive, they were still popular among the students. 
In contrast to the results about the textbooks, the participants had more positive opinions about the e-learning environments of the program in general and even the statements that they agreed with most on average were in this part of the questionnaire after the part about the general level of satisfaction with the program. Among the participants who responded to the open-ended question about the PRPP learning environments, 41 students expressed their satisfaction with the learning environments. Despite their positive attitudes towards the e-learning environments, the participants had a lower level of agreement with the statement on the adequacy of the content coverage of this platform. Also, the participants' self-reported need for more exam practice questions was again evident in other responses to the same question. In fact, 21 responses among these expressed this need in some way.

The participants had relatively less positive opinions about the PRPP measurement and evaluation practices. For example, the majority of the participants stated that the number of questions in the exams was sufficient and time given in exams was sufficient. Similarly, the vast majority of the participants in 2016 AU report (AU, 2016) and in the studies of Karadag (2014) and Usta (2015) stated that the number of questions in the exams was sufficient and time given in OEF exams was sufficient. However, the statements that the participants agreed with least on average were in the part about the PRPP measurement and evaluation processes after the one about the textbooks. In addition, only one third of the students thought the principle that midterm exams weigh $30 \%$ and final exams weigh $70 \%$ of a student's achievement grade in a course was appropriate. Similarly, 59\% of the participants in 2016 AU report stated that the OEF grading system made it difficult to pass courses and 57\% stated that the grading system did not measure the level of knowledge in a course appropriately (AU, 2016). In fact, nearly half of the answers to the relevant open-ended question revealed the students' dissatisfaction with the examinations of the courses due to the rule "one-fourth point is deducted for each wrong answer". By the same token, only 12 students expressed their satisfaction. To sum up, the participants' concerns about exams became more evident in both the closed-ended and open-ended questions directly related to the measurement and evaluation processes.

This concern was noticeable even in the questionnaire parts about other PRPP components. The most noteworthy results regarding the propositions for the improvement of the program were also related to the subject of measurement and evaluation in some way. The vast majority of the participants stated that they needed make-up exams (80.8\%). Among the all the statements in the questionnaire as separate items, the highest level of agreement by the participants was in this item. Surprisingly, very few students addressed this issue in their responses to the relevant open-ended question. This need was also evident among the results in the study by Usta (2015). On the other hand, more than half of the participants in our study stated that multiple-choice tests were suitable for measuring academic achievement and, in the same way, only $25.4 \%$ of them stated that other types of questions (e.g., true-false, open-ended, matching, etc.) should be used in addition to the multiple-choice questions. On the contrary, both Kara (2009) and Karadag (2014) investigated the measurement and evaluation practices of AUOES, and they both reached the conclusion that using true-false, gap-filling or matching type questions in addition to multiple-choice tests would be appropriate in some courses. Nevertheless, again in the study by Karadag (2014), 7.9\% of all OEF students preferred matching type questions and only $1.3 \%$ of them preferred essay type exam questions whereas, among the PRPP students in the same study, $6.8 \%$ preferred matching type questions and only $1.9 \%$ of them preferred essay type exam questions, which is a similar result to ours. The fact that the participants had relatively less positive attitudes about the measurement and evaluation processes of the program and they often mentioned their complaints with the current grading procedures, even in open-ended questions asking for something other than grading could be a result of the exam oriented in Turkish education system as Altan (2014) suggests. In fact, around half of the participants who responded to the open-ended question about their comments or suggestions to find solutions to the problems about PRPP components expressed recommendations about the PRPP measurement and evaluation processes.

On the other hand, the majority of the participants stated that they were pleased to study in this program, they would recommend PRPP to another friend, and the program of PRPP should be continuously developed and expanded. Therefore, generally speaking, the participants were satisfied with the program.

Among all the groups in this study, the participants who were employed had less positive attitudes towards all the parts in the questionnaire. Also, their overall level of satisfaction with the program was also lower than the other groups. This result is similar to the data obtained in the study by Usta (2015), who found 
that employed students had less positive opinions about the program components of OEF Social Sciences. In the same way, Esgice (2015) asserted that having a job was a serious environmental factor in ODL that distracted learners and led their attention away from learning. Individuals who have a job and, therefore, have less opportunity to spend time with the components of a program, especially with learning contents and environments, could have more positive attitudes when they have the opportunity to get to know these components more.

In terms of the reasons for enrolling in PRPP, the participants who stated that they enrolled in the program to prove themselves had more positive opinions about all the program components except for the program objectives. The reason for this result may be that the participants with the ambition of proving themselves tend to have stronger achievement orientation. On the other hand, the participants who stated that they enrolled in PRPP to improve their general culture had less positive opinions about all the parts in the questionnaire.

In terms of the type of enrollment in PRPP, the participants who enrolled through the second university option had more positive opinions about all the program components. This result might be due to the possibility that individuals who have already been admitted to a higher education program through the central student placement examination system tend to have stronger achievement orientation.

In terms of willingness to continue with a bachelor's degree after graduation from PRPP, the participants who had such a wish had more positive opinions about all the program components. According to Turkish higher education regulations, students enrolled in associate degree programs can continue with a bachelor's degree in a relevant major provided that they have high cumulative grade average points and score high in a transfer admission exam. We could suggest that those students with such an ambition tend to be more motivated to study and adopt the program more.

In terms of the use of the PRPP learning environments, the participants who used Anadolum e-Campus had more positive attitudes towards all the components of the program. On the contrary, the participants who did not use Anadolum e-Campus had less positive attitudes towards all the components of the program. This result is interesting since it suggests that use of the PRPP e-learning environments, Anadolum e-Campus, could affect students' perceptions of the program components. In fact, the second highest level of agreement by the participants with the statements in all parts of the questionnaire was in the part about the e-learning environments within the learning environments of the program. In other words, on average the participants had quite positive attitudes towards the PRPP learning environments. These results are consistent with each other. Similarly, according to 2016 AU report (AU, 2016), 92\% of students in AUOES stated that they used the e-learning platform, 36\% found the knowledge content of the e-learning platform very good and $26 \%$ found knowledge presentation very good, but more than half of the students who stated they did not use the platform explained that they had been unaware of this service.

Overall, our results demonstrate the participants' high level of satisfaction with PRPP. In other words, the majority of the participants stated that they were pleased to study in PRPP and they would recommend it to their friends. Another important conclusion that can be drawn is that the participants had quite positive attitudes towards the e-learning environments of PRPP. In fact, the use of Anadolum e-Campus by the vast majority of the participants confirms this finding. This finding could also be interpreted to verify almost four-decade-long experience and expertise of OEF in e-learning delivery as well as the satisfaction of students with this learning experience. On the other hand, the results revealed the participants had less positive attitudes towards the PRPP textbooks and measurement and evaluation processes. As a matter of fact, the participants' lowest level of agreement was found to be with these two statements in the questionnaire: "The principle that midterm exams weigh $30 \%$ and final exams weigh $70 \%$ of a student's achievement grade in a course is appropriate" and "Other types of questions (e.g., true-false, open-ended, matching) should also be used in addition to multiple-choice questions. This relatively less positive attitude of the participants about the measurement and evaluation processes of PRPP was also observed in responses to the open-ended questions, too.

The results revealed that more than half of the participants did not follow the exam preparation guidelines recommended for OEF examinations and they had relatively less positive attitudes towards the measurement and evaluation processes of PRPP. Therefore, it is recommended that the faculty should improve the academic 
counseling services offered to students about these processes. This could also help eliminate students' concerns about the grading procedure (e.g., one-fourth point is deducted for each wrong answer and midterm exams weigh $30 \%$ and final exams weigh $70 \%$ of a student's achievement grade in a course). It is also recommended that the extent to which PRPP learning contents improve professional knowledge should be investigated, the content of the e-learning environments should be expanded, and PRPP students should be provided with more information about the validity of the diploma to be given on their graduation. Also, in this study, a relationship was found between the participants' use of Anadolum e-Campus and their attitudes towards PRPP components. It is recommended that students should be provided with more information about this platform. In addition, as there is currently no unit within AUOES to evaluate the program of PRPP or any other programs, establishing a program evaluation unit or center could contribute to the ODL practices of AU. Finally, since the majority of the participants stated that they thought PRPP should be evaluated and expanded continuously and this is what research suggests, it is recommended that program evaluation and improvement studies for PRPP should be conducted periodically.

There are some paths that future research on this topic could follow. To begin with, data from studies to be conducted with focus group interviews could yield in-depth information about student perceptions of PRPP components. Also, the participants using the learning environments of PRPP were found to have more positive attitudes towards the program components in general. On the other hand, the existence of users with less positive attitudes towards PRPP components although they did not use the learning environments makes it important to reveal the direction of the cause-effect relationship between the two cases. Therefore, one could suggest that determining whether there is a relationship between learners' use of the learning environments of an ODL program and their attitudes towards the program components could yield significant data.

Authors' Note: This paper was extracted from H. Mustafa Donmez's PhD dissertation titled "Evaluation of the Public Relations And Publicity Two-Year Degree Program of Open Education Faculty and Proposals for Improvement" supervised by Prof. Dr. Ayhan Hakan, and part of it was presented as a paper at ICSE-2018.

\section{BIODATA and CONTACT ADDRESSES of AUTHORS}

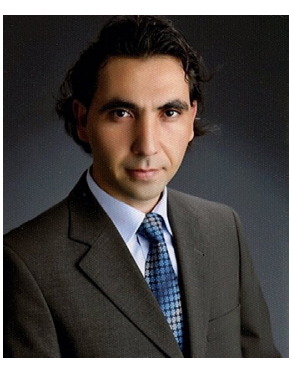

Dr. H. Mustafa DONMEZ, is an instructor at Department of Foreign Languages at Eskisehir Osmangazi University (ESOGU). Dr. Donmez gained his Ph.D. in Distance Education from Anadolu University in June, 2018. He has a Bachelor's Degree in Foreign Language Education from Middle East Technical University (METU) and a Master's Degree in Comparative Literature from ESOGU. His primary research interests include program evaluation in open and distance learning, instructional design for open and distance learning environments, and sociology of open and distance learning. He is currently the coordinator of Online Basic English Courses at ESOGU.

Mustafa DONMEZ

Address: Department of Foreign Languages, Eskisehir Osmangazi University, Meselik Campus, 26480, Odunpazari, Eskisehir, Turkey

Phone: +90 5322651377

E-mail: hmdonmezz@gmail.com,hmdonmez@ogu.edu.tr 


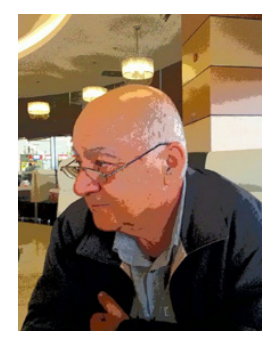

Dr. Ayhan HAKAN, graduated from Ankara University, Faculty of Educational Sciences in 1971. He completed his master's and doctoral studies at the same university. While he was doing his doctorate, he worked as Research and Development Branch Manager and Secretary General of the Inter-Academy Council of Economic and Commercial Sciences at the Ministry of National Education. He worked at Ankara University Faculty of Educational Sciences between 1980 and 1983. He received his associate professorship and professorship degrees at Anadolu University. Almost all of his duties at Anadolu University (30 years) passed in Open Education Faculty. He took part in the establishment of Anadolu University Institute of Educational Sciences. He has taught and supervised postgraduate courses at the Graduate School of Educational Sciences and Social Sciences Institutes. He retired from Anadolu University in 2016. In 2017, he worked at Maltepe University. His research interests are Curriculum Development, Research Education and Multimedia Education.

Ayhan HAKAN

Address: Open Education Faculty, Anadolu University,

Yunus Emre Campus 26470, Tepebasi, Eskisehir, Turkey

Phone: +905322383860

E-mail: ahakan@anadolu.edu.tr

\section{REFERENCES}

Aluka, F. R., Shonubi, O. K. (2014). Going beyond Kirkpatrick's training evaluation model: The role of workplace factors in distance learning transfer. Africa Education Review 114, 638-657. Retrieved from http://www.tandfonline.com/doi/abs/10.1080/18146627.2014.935007.

Altan, M. Z. (2014). Turkiyénin egitim cikmazi: Girisimci ogretim-girisimci ogretmen [Turkey's educational dilemma: Entrepreneur education- entrepreneur teacher], (2nd ed.). Ankara: Pegem Akademi.

Anadolu University. (2016). 2016-2017 ogretim yili guz donemi Acikogretim sistemine iliskin ogrenci gorusleri [Students' views on the open education system in fall semester of 2016-2017 academic year]. Eskisehir: Anadolu University.

Anadolu University. (2017). Acikogretim sistemi programlardaki ogrenci sayilarinin farkli kriterlere gore dagilimi [The distribution of the numbers of students in open education programs according to different criteria]. Eskisehir: Anadolu University.

Anadolu University. (2018a). Anadolu University information package. Retrieved from http://abp.anadolu. edu.tr/tr

Anadolu University. (2018b). Research and development unit for learning technologies 2017-2018 annual report. Eskisehir: Anadolu University.

Anderson, J. \& Dron, J. (2011). Three generations of distance education pedagogy. International Review of Research in Open and Distance Learning. 12 3, 80-97.

Ascough, R. S. (2002). Designing for online distance education: Putting pedagogy before technology. Teaching Theology \& Religion, 5(1), 17-29.

Ayvaz, Z. (2001). Egitim programi ve unsurlari [Educational program and its components]. (Unpublished master's thesis). Ataturk University, Erzurum, Turkey.

Balci, A. (1995). Sosyal bilimlerde arastirma, yontem, teknik ve ilkeler [Research, methods, techniques and principles in social sciences]. Ankara: 72 TDFO.

Baraz, G. (2005). Buro yonetimi ve sekreterlik onlisans programinin degerlendirilmesi [Evaluation of office management and executive assistant training program]. (Unpublished master's thesis). Anadolu University, Eskisehir, Turkey.

Bartlett, J. E., Kotrlik, J. W. \& Higgins, C. C. (2001). Organizational research: Determining appropriate sample size in survey research. Information Technology, Learning, and Performance Journal, 19(1), 43-50. 
Bas, T. (2001). Anket [The questionnaire]. Ankara: Seckin.

Bayrak, B. \& Erden, A. M. (2007). The evaluation of science curriculum. Kastamonu Journal of Education, 15(1), 137-154. Retrieved from http://www.kefdergi.com/pdf/15_1/137.pdf

Boody, R. M. (2009). A Rationale for participant evaluation. Educational Research Quarterly, 32(3), 47-59. Retrieved from https://search.proqAUOst.com/docview/216197994?pq-origsite=gscholar

Braimoh, D. (2003). Institutional and programme evaluation. In S. Panda (Ed.), Planning and management in distance education (pp. 209-218). London: Kogan Page.

Brown, J. D. (1995). The elements of language curriculum. Boston: Heinle and Heinle.

Buyuk, K., Kumtepe, A. T, Uca Gunes, E. P., Kocdar, S., Karadeniz, A., Ozkeskin, E. E., Gunes, I., Kara, Y. \& Ozturk A. (2018). Uzaktan ogrenenler ve ogrenme malzemesi tercibleri [Distance learners and their learning material preferences]. Eskisehir: Anadolu University.

Creswell, J. W., \& Plano Clark, V. L. (2011). Designing and conducting mixed methods research (2nd ed.). Thousand Oaks, CA: Sage.

Cousins, J. B. \& Earl, L. (Eds.). (1995). Participatory evaluation in education: Studies in evaluation use and organizational learning. London: Falmer.

Cetinsaya, G. (2014). Buyume, kalite, uluslararasilasma: Turkiye yuksekogretimi icin bir yol haritasi [Growth, quality, internationalization: a roadmap for Turkey's higher education]. Ankara: Turkish Council of Higher Education.

Daniel, J. S. (1996). Mega-universities and knowledge media: Technology strategies for higher education. UK: Psychology Press.

Duan, W., Gu, B. \& Whinston, A. B. (2008). Do online reviews matter?-An empirical investigation of panel data. Decision Support Systems, 45(4), 1007-1016.

Eksioglu, S., \& Taspinar, M. (2014). Evaluation of modular education program implementation in vocational and technical high schools. International Journal of Human Sciences, 11(2), 1203-1223. Retrieved from https://www.j-humansciences.com/ojs/index.php/IJHS/article/view/3095

Erden, M. (1998). Egitimde program degerlendirme [Program evaluation in education]. (3rd ed.). Ankara: Ani.

Erturk, S. (2013). Egitimde program gelistirme [Program development in education]. (6th ed.). Ankara: Edge Akademi.

Esgice, M. (2015). Acik ve uzaktan egitim ogrencilerinin okul birakma sebepleri [Reasons for open and distance education students' drop-out]. (Unpublished master's thesis). Ataturk University, Erzurum, Turkey.

Fitzpatrick, J. L., Sanders, J. R. \& Worthen, B. R. (2004). Program evaluation. alternative approaches and practical guidelines. (3rd ed.). USA: Pearson Education, Inc.

Garrett, R. (2016). The state of open universities in the Commonwealth: A perspective on performance, competition and innovation. Burnaby: Commonwealth of Learning. Retrieved from http:// oasis.col.org/bitstream/handle/11599/2048/2016_Garrett_State-of-Open-Universities. pdf?seqAUOnce $=1$ \&isAllowed $=y$

Hakan, A. (1991). Egitim onlisans programinin degerlendirilmesi [Evaluation of Education associate degree program]. Eskisehir: Anadolu University.

Hakan, A. (1996). Uzaktan ogretim yontemiyle egitim veren Anadolu Universitesi fakultelerinin tanitimi ve Bati Avrupa acikogretim programlarinin degerlendirilmesi [Presentation of the distance education faculties of Anadolu University and evaluation distance education programs in Western Europe]. Eskisehir: Anadolu University.

Hakan A., Ozgur A. Z., Toprak, E., Aydin, S., \& Firat, M. (2013). Acikogretim ogrencilerinin ozellikleri ile ogrenme ve iletisim ortamlarina iliskin egilimleri [Characteristics of open education students and their tendencies in learning and communication environments]. Eskisehir: Anadolu University. 
Hogan, L. R. (2007). The historical development of program evaluation: Exploring the past and present. Online Journal of Workforce Education and Development, 2(4), 1-14. Retrieved from http:// opensiuc.lib.siu.edu/ojwed/vol2/iss4/5/

Inglis, A. (2003). Planning and management of networked learning. In S. Panda (Ed.), Planning and management in distance education (pp. 159-168). London: Kogan Page.

Kara, E. (2009). Uzaktan yuksekogretimde olcme degerlendirme ve Anadolu Universitesi Acikogretim sistemi uygulamasi [Distance measurement in higher education and Anadolu University Open University system case]. (Unpublished doctoral dissertation). Anadolu University, Eskisehir, Turkey.

Karadag, N. (2014). Acik ve uzaktan egitimde olcme ve degerlendirme: Mega universitelerdeki uygulamalar [Assessment in open and distance education: practices in mega universities]. (Unpublished doctoral dissertation). Anadolu University, Eskisehir, Turkey.

Kesim, M. \& Altinpulluk, H. (2015). A Theoretical Analysis of Moocs Types From A Perspective of Learning Theories. 5th World Conference on Learning, Teaching and Educational Leadership (WCLTA 2014), $186,15-19$.

Khan, A. R. \& Garg, S. (2003). Material production and distribution, and operations management. In S. Panda (Ed.), Planning and management in distance education (pp. 135-143). London: Kogan Page.

Kocabatmaz, H. (2011). Teknoloji ve tasarim ogretim programinin degerlendirilmesi [The evaluation of the technology and design curriculum]. (Unpublished doctoral dissertation). Ankara University, Ankara, Turkey.

Kristoffersen, D. (2003). Denmark. Educational evaluation around the world: An international anthology. The Danish Evaluation Institute. Retrieved from http://english.eva.dk/publications/educationalevaluation-around-the-world-an-international-anthology/download

Kucuk, O. (2008). An evaluation of English language teaching program at key stage I and the opinions of teachers regarding the program. (Unpublished master's thesis). Canakkale 18 Mart University, Canakkale, Turkey.

Leiner, B. M., Cerf, V. G., Clark, D. D., Kahn, R. E., Kleinrock, L., Lynch, D. C., Postel, J. B., Lawrence G. R., \& Wolff, S. S. (1998). A brief history of the internet. Modeling, Life Prediction, and Computer Applications, 329, 21-32.

McKinney, D., Dyck, J. L., \& Luber, E. S. (2008). iTunes University and the classroom: Can podcasts replace professors? Computers \& Education, 52, 617-623.

Mcnamara, C. (2009). Leaders coaching leaders. Leadership Excellence, 26 (12), 18-19.

McNeil, J. D. (1996). Curriculum: A comprehensive introduction. (5th ed.). Los Angeles: Harper Collins College Publishers.

Mede, E. \& Akyel, A. (2014). Design of a language preparatory program: A case study. Journal of Theory and Practice in Education, 10 (3), 643-666. Retrieved from http://dergipark.gov.tr/http-eku-comuedu-tr/issAUO/5461/74072

Moore, M. G. \& Kearsley, G. (2005). Distance education: a systems view. Belmont, CA: Thomson Wadsworth.

Nas, R. (2003). Hayat bilgisi ve sosyal bilgiler ogretimi [Teaching Social Sciences]. Bursa: Ezgi.

Oblinger, D. \& Kidwell, J. (2000). Distance learning: are we being realistic? Educause Review, 35 (3), 30-39.

Ornstein, A. C. \& Hunkins, F. P. (2004). Foundations, principles and issues. (3rd ed.). Needham Heights, MA: Allyn.

Ozkul, A. E. \& Aydin, C. H. (2012). Ogrenci adaylarinin acik ve uzaktan ogrenmeye yonelik gorusleri [Prospective students' views on open and distance learning]. Akademik Bilisim 2012, Usak: Usak University.

Paul, R. H. (2003). Institutional leadership and the management of change. In S. Panda (Ed.), Planning and management in distance education (pp. 75-86). London: Kogan Page. 
Posner, G. J. (2004). Analyzing the curriculum. (3rd ed.). United States of America: McGrow-Hill Inc.

Powar K. B. (2003). Management of institutions, In S. Panda (Ed.), Planning and management in distance education (pp. 60-68). London: Kogan Page.

Shah, D. (2018). By the numbers: MOOCS in 2017. Class central. Retrieved from https://www.classcentral.com/report/mooc-stats-2017/.

Sercek-Ozaltas, G. (2014). Onlisans turizm egitim programinin CIPP modeline gore degerlendirilmesi [Evaluation of Tourism Education Program by CIPP Model]. (Unpublished doctoral dissertation). Dicle University, Diyarbakir, Turkey.

Simonson, M., Smaldino, S., Albright, M., \& Zvacek, S. (2006). Teaching and learning at a distance: Foundations of distance education (3rd ed.). Upper Saddle River, NJ: Pearson.

Stake, R. E. (1967). The countenance of educational evaluation. Teachers College Record, 68 (7), 523-540. Retrieved from http://www.tcrecord.org/library/abstract.asp?contentid=2184

Stufflebeam, D. L. (1971). The use of experimental design in educational evaluation. Journal of Educational Measurement, 8(4), 267-274. Retrieved from http:/onlinelibrary.wiley.com/ doi/10.1111/j.1745-3984.1971.tb00936.x/full

Taba, H. (1962). Curriculum development: theory and practice. New York, NY: Harcourt, Brace \& World.

Tait, A. \& Mills, R. (1999). The convergence of distance and conventional education: Patterns of flexibility for the individual learner. In A. Tait and R. Mills (Eds.), The convergence of distance and conventional education: Patterns of flexibility for the individual learner (pp. 2-4). London and New York: Routledge.

Tamkin, P., Yarnall, J. \& Kerrin M. (2002). Kirkpatrick and Beyond: a review of training evaluation. Brighton, UK: The Institute for Employment Studies. Retrieved from http://www.employmentstudies.co.uk/system/files/resources/files/392.pdf.

Tunc, F. (2010). Evaluation of an English language teaching program at a public university using CIPP model. (Unpublished master's thesis). Middle East Technical University, Ankara, Turkey.

Turkish Council of Higher Education. (2018). Yuksekogretim bilgi yonetim sistemi [Higher education information management system]. Retrieved from https://istatistik.yok.gov.tr/

Tyler, R. W. (2013). Basic principles of curriculum and instruction. Chicago and London: The University of Chicago Press.

Ucar, H. (2012). Ingilizce ogretmen adaylarinin ozyeterlik inanci, basari yonelimi ve cevrimici ogrenme ortamina katilim durumu: Uzaktan IOLP ornegi [Preservice English language teachers' selfefficacy beliefs, goal orientations and participation in online learning environment: A study of a distance English language teacher education program]. (Unpublished master's thesis). Anadolu University, Eskisehir, Turkey.

Usta, I. (2015). Acikogretim Fakultesi Sosyal Bilimler Onlisans programinin degerlendirilmesi ve gelistirilmesine yonelik oneriler [Evaluation of Open Education Faculty social sciences program]. (Unpublished doctoral dissertation). Anadolu University, Eskisehir, Turkey.

Usun, S. (2012). Egitimde program degerlendirme: Surecler yaklasimlar ve modeller [Program evaluation in education: Processes, approaches and models]. Ankara: Ani.

Yavuz, M. I. (2007). Anadolu Universitesi Acikogretim Fakultesi Polis Meslek Egitimi onlisans programinin degerlendirilmesi [Assessment of occupational training program for the police force in Anadolu University Open Education Faculty]. (Unpublished master's thesis). Anadolu University, Eskisehir, Turkey.

Yuksel, I.\& Saglam, M. (2014). Egitimde program degerlendirme [Program evaluation in education]. (2nd ed.). Ankara: Pegem. 


\section{APPENDIX}

\section{Evaluation Survey for Public Relations and Publicity Program}

\section{EVALUATION SURVEY FOR PUBLIC RELATIONS AND PUBLICITY PROGRAM}

Dear students,

Educational programs need evaluating so that whether they have achieved their goals can be determined and they can be improves. One of the ways of this evaluation is to determine the stakeholders' perceptions of the objectives, content, learning environments and measurement and evaluation processes of a program.

In this respect, we would like to evaluate Public Relations and Publicity program based on your opinions. You can guide us in improving the program practices with your sincere responses.

This questionnaire includes questions about your personal information, the evaluation of program components and the overall evaluation of the program. After answering the questions about personal information, you can indicate your level of agreement with the statements about the program by choosing "Strongly Disagree, Disagree, Neither Disagree Nor Agree, Agree, or Strongly Agree".

We would like to express our sincere gratitude to you for your valuable contribution to evaluation and improvement of this program.

Instructor H. Mustafa DONMEZ

Doctoral student in Distance Education

I confirm that I participate in this study voluntarily and I understand I have the right to withdraw from the study at any time without having to give a reason. I agree that my data will be acquired and stored for scientific purposes.

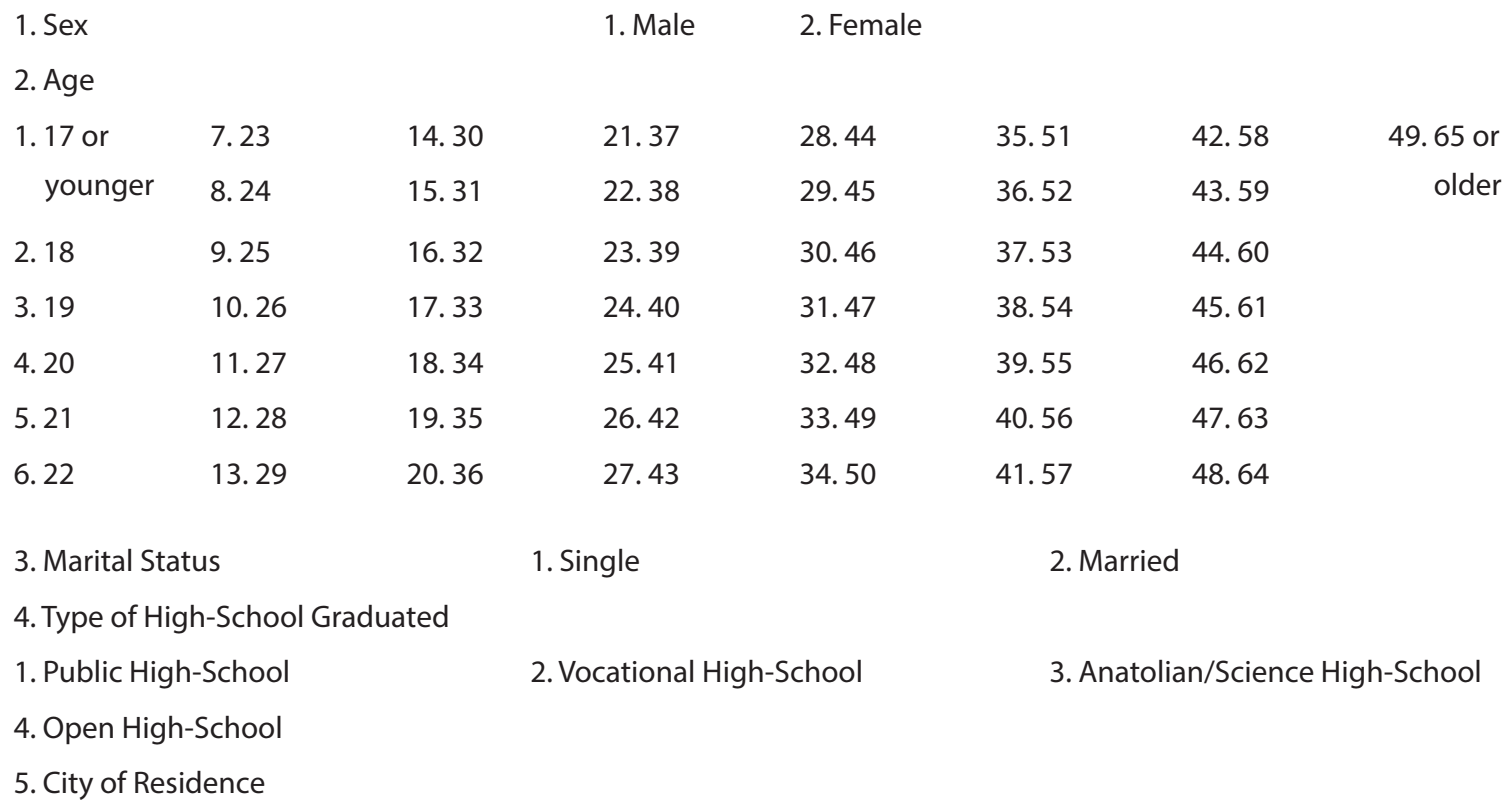




$\begin{array}{llll}\text { 1. Adana } & \text { 22. Canakkale } & \text { 43. Karabuk } & \text { 64. Osmaniye } \\ \text { 2. Adiyaman } & \text { 23. Cankiri } & \text { 44. Karaman } & \text { 65. Rize } \\ \text { 3. Afyonkarahisar } & \text { 24. Corum } & \text { 45. Kars } & \text { 66. Sakarya } \\ \text { 4. Agri } & \text { 25. Denizli } & \text { 46. Kastamonu } & \text { 67. Samsun } \\ \text { 5. Aksaray } & \text { 26. Diyarbakir } & \text { 47. Kayseri } & \text { 68. Sanliurfa } \\ \text { 6. Amasya } & \text { 27. Duzce } & \text { 48. Kilis } & \text { 69. Siirt } \\ \text { 7. Ankara } & \text { 28. Edirne } & \text { 49. Kirikkale } & \text { 70. Sinop } \\ \text { 8. Antalya } & \text { 29. Elazig } & \text { 50. Kirklareli } & \text { 71. Sivas } \\ \text { 9. Ardahan } & \text { 30. Erzincan } & \text { 51. Kirsehir } & \text { 72. Sirnak } \\ \text { 10. Artvin } & \text { 31. Erzurum } & \text { 52. Kocaeli } & \text { 73. Tekirdag } \\ \text { 11. Aydin } & \text { 32. Eskisehir } & \text { 53. Konya } & \text { 74. Tokat } \\ \text { 12. Balikesir } & \text { 33. Gaziantep } & \text { 54. Kutahya } & \text { 75. Trabzon } \\ \text { 13. Bartin } & \text { 34. Giresun } & \text { 55. Malatya } & \text { 76. Tunceli } \\ \text { 14. Batman } & \text { 35. Gumushane } & \text { 56. Manisa } & \text { 77. Usak } \\ \text { 15. Bayburt } & \text { 36. Hakkari } & \text { 57. Mardin } & \text { 78. Van } \\ \text { 16. Bilecik } & \text { 37. Hatay } & \text { 58. Mersin } & \text { 79. Yalova } \\ \text { 17. Bingol } & \text { 38. Igdir } & \text { 59. Mugla } & \text { 80. Yozgat } \\ \text { 18. Bitlis } & \text { 39. Isparta } & \text { 60. Mus } & \text { 81.Zonguldak } \\ \text { 19. Bolu } & \text { 40. Istanbul } & \text { 61. Nevsehir } & \\ \text { 20. Burdur } & \text { 41. Izmir } & \text { 62. Nigde } & \\ \text { 21. Bursa } & \text { 42. Kahramanmaras } & \text { 63. Ordu } & \end{array}$
6. Year of Study
7. Are you employed?
8. Reason for enrollment in the program
1. To be knowledgeable in my field of interest
2. To get a job
3. To get promoted/higher pay at work
4. To catch the education opportunity I missed in the past
5. To obtain a university diploma
6. To create a new job opportunity
1. 1
1. No
2. Yes

10. Because my level of income is not sufficient for education in another city

11. To delay my compulsory military service

12. To prove myself

13. Because having an open education diploma is a privilege

14. To earn a respectable social status

15. My exam score was only sufficient for distance education

16. To be a university student

17. Because people around me encouraged me

9. Type of enrollment in the program

1. New Student Admission (Central Student Placement Exam) 2. Transfer Admission

3. Second University

10. Are you willing to continue with a bachelor's degree after graduating from this program?
1. No
2. Yes

11. How often do you use open education system learning environments?

\begin{tabular}{|l|l|l|l|}
\hline & Never & Rarely & Very often \\
\hline Printed Book Services & & & \\
\hline Anadolum e-Campus System & & & \\
\hline Face-to-face Classes & & & \\
\hline
\end{tabular}


12. The recommended preparation steps for Open Education Faculty exams is as follows:

- First, study the relevant course book and answer the end-of-unit questions.

- Then, watch the lecture videos of the related course and answer the e-practice questions in the e-learning platform.

- Finally, check your level of knowledge with the e-exam application.
Do you follow the steps above when preparing for exams?
1. No
2. Yes

The following are statements about the objectives, content, learning environments, and measurement and evaluation
processes of Public Relations and Publicity Program. Please indicate your level of agreement with each statement.
(1=Strongly Disagree, $2=$ Disagree, $3=$ Neither disagree not agree, $4=$ Agree, and $5=$ Strongly Agree).

\begin{tabular}{|l|l|l|l|}
\hline \multicolumn{1}{|c|}{ EVALUATION OF THE PROGRAM Program objectives } & & & \\
\hline 1. are stated clearly. & & & \\
\hline 2. can meet learners' needs & & & \\
\hline 3. can be used in everyday life. & & \\
\hline
\end{tabular}

2. can meet learners' needs

3. can be used in everyday life.

4. can achieve program objectives.

5. improve general culture.

6. are detailed enough.

7. are clear and easy to understand.

8. consist of connected knowledge.

9. improve professional knowledge.

\begin{tabular}{|l|l|l|l|}
\hline \multicolumn{1}{|c|}{ Textbooks } & & & \\
\hline $\begin{array}{l}\text { 10. have quality prints to make reading easy. } \\
\text { 11. have sufficient number of pages. }\end{array}$ & & & \\
\hline $\begin{array}{l}\text { 12. have units with equal amounts of knowledge. } \\
\begin{array}{l}\text { 13. have sections of sample cases, key concepts, info boxes, practice questions, summaries, and } \\
\text { reading passages to ensure effective learning. }\end{array}\end{array}$ & & & \\
\hline \begin{tabular}{l} 
14. have units with sufficient number of exam practice questions each. \\
\hline
\end{tabular} & & & \\
\hline
\end{tabular} e-Learning environments (Anadolum e-Campus)

15. contain all the knowledge related to the program.

16. supplement the textbooks.

17. prepare for the exams.

18. facilitate learning.

19. ensure revision of the subjects.

20. are suitable for individual learning.

21. can be used by anyone with basic computer skills. In terms of measurement and evaluation processes,

22. exam questions are consistent with textbook contents.

23. the number of questions in the exams is sufficient.

24. time given in exams is sufficient.

25. preparation time durations for midterm exams and final exams are sufficient.

26. the principle that midterm exams weigh $30 \%$ and final exams weigh $70 \%$ of a student's achievement grade in a course is appropriate.

27. multiple choice tests are suitable for determining academic achievement.

28. exam questions measure level of knowledge.

29. applying a lower limit of achievement grade is appropriate.

30. determining a student's achievement grade based on his or her performance relative to the class as a whole is an appropriate assessment. OPINIONS AND RECOMMENDATIONS FOR IMPROVING THE PROGRAM

31. The announcement duration of exam results is appropriate.

32. Make-up exams are needed.

33. e-Learning environments are easily accessible.

34. There is a need for supplementary resources summarizing the textbooks.

35. Books can be carried easily. 


\begin{tabular}{|l|l|l|l|}
\hline 36. Face-to-face classes are needed. & & & \\
\hline $\begin{array}{l}\text { 37. Other types of questions (e.g., True-False, Open-Ended, Matching, etc.) should also be used in } \\
\text { addition to multiple-choice questions. }\end{array}$ & & & \\
\hline $\begin{array}{l}\text { 38. I am provided with sufficient information about the validity of the diploma to be given when I } \\
\text { graduate. }\end{array}$ & & & \\
\hline 39. This program should be continuously developed and expanded. & & & \\
\hline 40. Elective courses should be diversified. & & & \\
\hline 41. We should be able to take courses in other programs. & & & \\
\hline \multicolumn{1}{|c|}{ GENERAL LEVEL OF SATISFACTION WITH THE PROGRAM } & & \\
\hline 42. I am pleased to study in this program. & & \\
\hline 43. I would recommend this program to another friend. & & & \\
\hline
\end{tabular}

44. If you have any comments or suggestions about the textbooks and content of your courses, please write here.

45. If you have any comments or suggestions about the learning environments of your courses, please write here.

46. If you have any comments or suggestions regarding the measurement and evaluation processes of your courses, please write here.

47. If you have any comments or suggestions to find solutions to the problems encountered in the teaching activities, please write here. 